\title{
The Long Thirteenth Century of the Chachnama
}

\section{Manan Ahmed}

\author{
Columbia University
}

\begin{abstract}
The multi-genre Persian text Chachnama, written in Uch in 1226, represents a unique formulation of a possible future for a Muslim polity at the frontier and under immense duress. In its explicit linkage of a Muslim with a local pre-Islamic past within the site and milieu of its production, the Chachnama presents the beginnings of a new political theology. Long understood as a translation of an earlier text, it is instead a specifically imagined text that found political and romantic resonance in the histories of Uch and Sindh through the centuries. This article provides a close reading of the text to elucidate the ways in which it participates in varied genres and the socio-political claims it makes on historiography. It further traces the historiography surrounding the text and highlights the ways in which classificatory schema (such as genre) operate on analytical understandings of narratives.
\end{abstract}

Keywords: Uch, Indo-Persian historiography, narrative, 'Ali Kufi, Chachnama, thirteenth century, genres, Delhi Sultanate

Acknowledgements: This article is dedicated to the memory of my father, Sultan Ahmed Asif (1939-2012). I am immensely grateful for the help and advice of Sonam Kachru, Rajeev Kinra, Saud al-Zaid, Prithvi Datta Chandra Shobhi, Sunil Kumar and the anonymous reviewers of the journal. All shortcomings remain mine.

\section{Introduction}

In March 2011, I went to Uch Sharif - a dusty, small town from which the river Indus changed its course many hundred years ago. This was my third visit to the town; previously in 2004 and 2006 I had worked in the private collections of two local families, examining one manuscript of the Chachnama - a text, in Persian, composed in that locale in 1224-26 by 'Ali Kufi. I was in a car, driving into Uch from Ahmedpur Shirkia with Syed Shahbaz Ali Bukhari, who owns a small

The Indian Economic and Social History Review, 49, 4 (2012): 459-491 SAGE Los Angeles/London/New Delhi/Singapore/Washington DC DOI: $10.1177 / 0019464612463804$ 
jewellery shop in that adjacent town. As we turned off the exit from the motorway and began to drive through the farmland, I looked at palm trees which flanked the road. Turning to him, I said, 'Palm trees! What are they doing so far in-land? The coast is a good eight hours away.' 'Well, they were planted here in Uch by Muhammad bin Qasim,' replied Bukhari. 'And how do we know this?' I asked. I was quite accustomed to hearing stories of Muhammad bin Qasim - a protagonist in the Chachnama, a Syrian Arab military commander who established Damascene rule in al-Sind in $712 \mathrm{CE}$ - told with pride or with dismay in rural Sindh and Punjab, but this time, I was surprised that the answer contained the memory of a text. 'It is written in Chachnama,' he turned to me and said, 'I assumed you would know, since you are the historian.' Such echoes of textual ghosts in contemporary Uch continued as conversation after conversation revolved around the various texts that emerged out of that particular Uch space and where they continue to hold imaginative sway. While the actual text of the Chachnama itself was barely visible - one manuscript copy in a private collection, an edited manuscript, out of print since the late 1980s, and a Sindhi translation, also unavailable - there were easily accessible stories, romantic or historic which were credited to, or derived from Chachnama. My basic question, one that I have tried to tackle since 2004, is simple: Why then, and how, does the Chachnama continue to live in Uch? To answer this question, I have to not only look at the text itself-what makes it available, or resonant — but also to Uch as a landscape, a habitus and a space.

The persistence of medieval narratives in contemporary lives and spaces is often understood via the stickiness of stories to built environment (the ability of narratives to cohere along monuments, of memories to frame ruins, of ghost-stories to affix themselves to houses, etc.) or to meta-structures such as religious or nationalist. As exemplified by Jean-François Augoyard or Michel de Certeau, there is the movement from lieu to espace which happens as narratives circulate in communities, attached to the landscape and the language politics of the site. When thinking about the stickiness of Chachnama in Uch, we are confronted with local notions of temporality, the archaeological weight of texts and an idea of Uch as a specific space- a capital at the edges of empire, a sacred site with centuries of spiritual heritage - which takes root in the narratives of the region from the early thirteenth century. That is, that there exists a particular discursive tradition in Uch within which are set of tropes, images, emotions and affiliations regarding this particular text, this site, this landscape and this space. It is a symbiotic relationship which is evidenced from Uch - varied groups of texts such as the Chachnama from 1226, Sufi Makhdum Jahaniyan's Safarnama from 1350, Mir Muhammad Ma'sum Bhakkari's Ta'rikh-i Ma 'sumi from 1600, or Mir 'Ali Shir Qana'i's Tuhfat-ul Kiram from 1788 - put forth an explicit engagement between narratives of the past and the landscape of Uch. Within these texts are notions of space, sacral and political, history, narratives of self and community, along with references to objects and sites which intertwine geographically, historically and historiographically to produce an idea of Uch. Take, 
for example, an early reference to Chachnama in 'Ayn ul-Mulk Abdullah Mahru's Insha'-i Mahru - a collection of administrative letters written during the reign of Firuz Shah Tughluq (1351-1388) by this governor based in Lahore. In a letter addressed to the Uch noble who was resisting taxation Mahru refers to a 'History of Dahir, son of Chach' (Ta'rīkh-i Dähir-i Chach) which is 'well known to the common people in the land of Sindh' (miyān 'äma' $i$ khälq diyār-i sind mashhür ast). ${ }^{1}$ In his letter Mahru, chiding the local noble for failure to pay taxes, narrates a story of feminine vile and masculine vapidity 'typical to the region' from the Chachnama. The textual citation works both to give weight to the insults delivered by Mahru and also to assert a historical link between the text and the space.

How does this presence of Chachnama and its relationship to Uch continue across the arrival of modernity, colonialism and the nationalist states? One can stress the unique power of the pre-eminent state which creates a memory and tradition of understanding for a community - a particularly dominant understanding which it puts in place via pedagogical, commemorative and spectacular means. This power of such shaping of the pasts relies on specific classificatory schema of the past (origins of the people or nation, or the golden age, etc.), on specific texts (be it the Ramayana or Germania) and their categorisations. Within this framework, scholarship takes the philologic or literary task of classification of various oral or written texts as myth, epic, romance or history, with an eye to discern the 'true history' or to extract the originary story. Without entering the well-trodden fields of Orientalist constructions of Muslim pasts, it is instructive to highlight how modern historiography continues to grapple with the question of classification, genre and what to make of historical pasts. This is, and has been, primarily a question of political power in knowledge production and not one attuned to how communities - micro or macro-choose to remember or forget their social pasts. My effort is to begin an argument for a more symbiotic relationship between space and text.

At the heart of what follows lies a basic set of questions about texts, about communities which nestle and sustain them, and about geographical and mental spaces both inhabit. My interest in this set of relationships, in understanding this text in its discursive tradition, and in memory and community, derives from an 'ethics of reading' to employ John Dagenais' formulation in his work on the fourteenth century Spanish Libro de beun amor of Juan Ruiz. Dagenais argues for connecting the manuscript culture to the particularities of reading and circulation in a community with space and understanding the transformative capacity of texts to arrive at an understanding of the particular consciousness of its audiences. Expanding further from Dagenais' formulation, I am interested, also, in an ethics of reading vis-àvis present historiography. Here, I am thinking particularly of how contemporary understandings and fetishes dissect and mine pre-modern texts either looking for historical fact or cultural tradition. The bulk of Indo-Persian historiography which

\footnotetext{
1 'Ain ud-Din Mahru, Insha'-i Mahru, p. 233.
} 
has dealt with the period between the thirteenth and the sixteenth century has followed a similar trajectory-segmenting authors into genres, slicing texts into anecdotes, in service of political history which focuses on the imperial capitals.

Yet, an argument towards explicating a narrative, dialogic relationship between text and space has to begin by returning to the text, via reading, and to the place, via ethnography. This present article comes into focus against that larger background - it focuses largely on the complex narrative texture of the Chachnama. The effort is to present in finely textured detail the shifts in genres and narrative voice which Chachnama employs and through which it makes an argument for a new political order. In concentrating on the text of Chachnama alone, I further make two claims on historiography: the need to examine the textual and situational wholeness of medieval texts (this would be a corrective to positivist historiography) and to move beyond over-determined genre-specified reading (that is, a history works in a particular way, a mystic text is some other way). It is clear that Chachnama occupies a certain relationship to both space and to conceptions of past and present (its past, its present) which enabled its circulation and resonance in Uch across centuries, even as it remained a marginal text from other vantage points, and in other geographies. My main effort, thus, is to do a close reading of the text of Chachnama and then to situate Chachnama materially and conceptually in Uch of the 1220s. In the first section of thearticle, I will turn to an analysis of the text and argue that it is only by considering the text-as-whole that we can apprehend the radical futures posited by the text. In the second, largely historiographical section, I want to highlight the effect of colonial and post-colonial classificatory schemas on our efforts at understanding this text.

Here, I want to point out that the period between the ninth and thirteenth century has benefited from some tremendous new scholarship in the past decade or so - focusing on historical, literary and material analysis - foremost being the work of Sunil Kumar, Sunil Sharma, Finbarr Flood and Blain Auer. This scholarship, in turn, rests on works reaching back to the beginning of the twentieth century with notable names such as M. Habib, Hodivala, N.A. Baloch, P. Hardy, Y. Friedmann, etc. Collectively we know the political and cultural terrain of Muslim al-Hind during that time period in immense and complicated detail — though there remain lacunae on the transition between Arab rule in al-Sind and the establishment of the Delhi Sultanate. Yet, it remains that Chachnama is either a silent participant in these discussions or (more negatively) used to pin one or two facts onto the paper. There is no full length study of Chachnama and neither has anyone made a case to do one. It remains an already digested text. This article is an opening gambit of a fuller study on the Chachnama, but one without which we cannot comprehend why we need a fuller study on the Chachnama.

\section{On Genres}

One key intervention in the study of pre-modern textual traditions comes in the synthesis on medieval South India textual productions by V. Narayana Rao, David

The Indian Economic and Social History Review, 49, 4 (2012): 459-491 
Shulman and Sanjay Subrahmanyam in their Textures of Time which argues vociferously that 'history possesses no fixed genre' and goes on to read a variety of texts produced from the fifteenth to the eighteenth century, written in Sanskrit, Telegu, Tamil, Marathi and Persian across South India with an aim to dismantle the overtly structural reading of post-Rankian history onto other spaces. ${ }^{2}$ For me, the most valuable contribution of their work is the geographical grounding they provide to some of the texts they discuss - asking us to consider the communities which gave birth to the narratives and with whose pasts and presents, these narratives are concerned. Though, their main effort is to trace an idea of history, of causality or genealogy, I am eager to develop another key claim from Textures of Time- the ways in which switches in genres, within the same text, signify historical movement, nods to new temporalities and interweaving of selfs and communities, and that within these juxtapositions is a newly created space that allows radically new imaginations of the past to come forth and circulate.

As Textures of Time itself discusses, Peter Hardy's classificatory schema for Persian histories written before the Mughal period remains a dominant paradigm in the field. ${ }^{3}$ Hardy drew upon H.A.R. Gibb to argue that with the passing of the golden age of Arabic historical writing (say with al-Tabari), Muslim historiography in India became 'theocratic rather than humanist' with no sense of their immediate pasts, concerned solely with the history of the ummah and without any progressive world-view. ${ }^{4}$ To Hardy most of the genres emerging in Persian India (universal history, hagiography, advice, or 'artistic forms'), either had 'facts subordinated to effect' or simply had a 'great disinclination for facts'. ${ }^{5}$ For Hardy, this meant an overarching theory of history and history writing in Muslim India - once historywriting left Arabia (and Arabic) it quickly denigrated from history. Consequent to this, Hardy argues that historical understanding for this time-period is 'literally composed of strata upon strata of frozen narratives' where historical tropes continue to reign. ${ }^{6}$ The 'frozen' narratives make the task of pre-Mughal historiography more dependent on the classificatory sense-making of genres, as it did for Hardy.

In more recent scholarship, the supposedly unassailable primary location of Arab historiography in the ninth until the tenth century has both been challenged, and interesting new questions have been asked. ${ }^{7}$ Yet, there is little traffic of ideas

${ }^{2}$ Rao et. al, Textures of Time, p. 221.

${ }^{3}$ Ibid., pp. 219-21.

${ }^{4}$ Hardy, 'Some Studies in Pre-Mughal Muslim Historiography', p. 127.

${ }^{5}$ Ibid., p. 123-25. Here I am reminded by Sonam Kachru of Matthew Kapstein's work on Tibetan history and memory where he succinctly argues: 'While contemporary academic historians of Tibet have generally felt it their charge to get at the facts of the matter to the extent possible, it has sometimes not been sufficiently considered that the apparent inaccuracies, legends, and fancies are among the facts of the matter (Kapstein, Tibetan Assimilation of Buddhism, p. 38).

${ }^{6}$ Ibid., p. 119.

${ }^{7}$ To cite a few key exemplars of the historiographical debate on al-Tabari, truth and narrativity, see El-Hibri (Reinterpreting Islamic Historiography, 1999), Heck ('Genres, Values and the Construction of 
across Arabic and Persian disciplinary realms (let it be also noted that similar lack of traffic exists within Tibetan/Buddhism/Islam archives in South Asia), and semblances of Hardy's views on the relationship of facticity to narrativity and of history to genre continue to hold purchase. ${ }^{8}$ Recently, I.H. Siddiqui (2010) argued that "there is a divergence in the approach of Arab historians of the Classical period and the compiler of Chachnama' where the first set is concerned only with meticulous presentation of facts and important details, and the second effort becomes valuable only once 'stripped of the tales of romance and other trivial matter'. ${ }^{9}$ Keshavmurthy in a literary study on 'Awfi, a contemporary of al-Kufi in Uch, concluded that 'at no point in any of the aforementioned medieval Persian texts, then, can we distinguish the universal and timeless claims of literary theoretical notions from the historically local political motivations of a text's author' and that 'performance of older universal literary conventions overtly shared by all classical Persian literature authorised and disguised local political motivations'. ${ }^{10}$ Such scholarly judgments retain a calcified outlook on Persian historiography — one unproblematically attached to Hardy—or to quote David Bowie 'I am always crashing in the same car'.

Whether in the mode of parsing texts for truth or for over-determining the influence of genre at the cost of specificity of locality and time, the pre-Mughal historiography has a long history of foreclosing meaning and understanding of texts. It is to this history of closed meanings that I want to turn now, to show how Chachnama's long afterlife is fractured between its locality and its universality.

\section{Brief Synopsis of Chachnama}

Nothing is known of 'Ali Kufi (b. 1158) outside of what he writes in the introduction to his text. He does not state the land of his origin, his previous habitats or the exact reason for his migration. He states simply that he spent the majority of his life in leisure and comfort but due to the 'accidents of life and the passage of time', he migrated to Uch and found some favour with the local Sultan Qabacha's chief minister, 'Ain-al Mulk Abu Bakr al-Ash'ari. To this same court, at that time, were gathered luminaries of the scholarly class-men like "Awfi (who completed his Lubab al-Albab) and Juzjani (who began his Tabaqat-i Nasiri there). In 1216, at the age of 58, he gave up all other concerns and decided to create 'a book of exceptional beauty and grace' (kitab-i nafees-ra anees ou jalees) telling of the wisdom and bravery with which Muhammad bin Qasim, in $712 \mathrm{CE}$, conquered

Knowledge', 2001), Judd ('Narratives and Character Development', 2005), Peterson ('Review of The History of al-Tabarī', 1999) and Lamoreaux (The Early Muslim Tradition of Dream Interpretation, 2002).

${ }^{8}$ In addition to Textures, the work of Daud Ali (2004), Samira Sheikh (2010) and Sunil Kumar (2010) have fruitfully challenged the prevalence of genre in historical analysis.

${ }^{9}$ Siddiqui, 'Chachnama and its Significance', p. 31.

${ }^{10}$ Keshvamurthy, 'Finitude and the Authorship of Fiction', p. 119.

The Indian Economic and Social History Review, 49, 4 (2012): 459-491 
al-Hind w'al Sind, besieged forts, built mosques and governed with wisdom. It was a text, Kufi writes, which would provide a key to the 'slaves of the Prophetic world' (bandagān-i dawlüt-i Muhammad) to govern. ${ }^{11}$ For the explicit sake of currying favour from Qabacha's court, he dedicated it to "Ain-al Mulk Fakhr al-Din Husain, the son of Qabacha's powerful minister. Reading his many attempts to deliver a suitably obsequious dedication, it becomes apparent that "Ali Kufi was never guaranteed any support from the court. Unlike Juzjani and 'Awfi, he had no official position, nor any salary from Qabacha. 'Ali Kufi, then, was not writing a 'court' chronicle as Juzjani did — a fact that sheds important light on our own reading of his text.

After the authorial notes, 'Ali Kufi provides his most apt title for his work, 'The Book of Stories of the King Dahir bin Chach bin Sila'ij and his Death at the hands of Muhammad bin Qasim' (Kitāb-i Hikayāt-i Rai Dāhir bin Chach bin Sila'̄̄j wa halāk shudan ou badāst-i Muhammad-i Qasim). Chachnama begins in the city of al-Aror and concerns the rise to power of a young, and talented Brahmin Chach bin Sila'ij and goes on to describe: the condition at al-Aror prior to Chach's arrival at the capital, his employment as a scribe for the King's chief minister, how the young Queen falls in love with him, and schemes to place him upon the throne of the kingdom after the death of the King; Chach's re-conquest of 'the four quarters' of the kingdom, his treatment of civilians and cities; the tussle between Chach's two sons Dahir and Dahirsena for the throne after Chach's death; the treacherous way in which Dahir takes over al-Aror; and finally the set-piece - the marriage of Dahir to his own sister. All of this, constituting the first third of the Chachnama, has three overarching themes: the basis of legitimacy for the ruler, the good council of the advisor and the immorality of treachery. Thus ends the Chach portion of the text. 'Ali Kufi narrates this section variously: 'the tellers of tradition and authors of histories' (rawiyān-i 'ahädìth ou mușannafan-i tawār' '̄kh), 'the author of this romance and the writer of this bouquet' (musannaf'ìn dastān ou muharrarīn bustān), 'writers of the story of this conquest' (hikayät nawisin fath) - at each moment in the narrative asserting both a textual precedence and an oral one-while also asserting a heterogeneity towards the conventions of various narrative genres.

The next portion of the text is introduced under the heading, "A History from the Righteously Guided Caliphs to al-Walid' - quite similar to the chapter headings of any annalistic history (such as, al-Tabari). Those episodes narrated by the generic 'tellers of traditions' dwindle, to be replaced with direct chains of transmissionAbu'l Hasan reports (abu'l hasan rawai'at kardān). There is the customary-for Arabic historiography - sprinkling of Arabic poetry in the text along with explicit mentions of those who did commendable and heroic deeds.

'Ali Kufi begins with the time of 'Umar and describes the attempts to take al-Hind. Short accounts of governors dispatched to various fronts in Makran,

\footnotetext{
${ }^{11}$ Baloch, Fathnama-i Sindh, p. 7.
} 
Zabulistan and Qandahar are followed by descriptions of rebellious groups fleeing to the frontier. He details the "Alawi revolts and the amassing of troops in al-Sind who were conspiring against the 'Umayyad governor al-Hajjaj bin Yusuf. He describes the ships, bearing Muslim women and gifts, which were captured by Mid pirates and the resulting call to action by Hajjaj. The campaign of Muhammad bin Qasim towards al-Hind and al-Sind follows, roughly as outlined in the history of al-Baladhuri, Futuh al-Buldan (c. $850 \mathrm{CE}$ ). 'Ali Kufi's narration is richer than that of al-Baladhuri, however, with a focus on the inner turmoil, deliberations, doubts and planning. The battle of Muhammad bin Qasim against Dahir features dreams, portents and the coming of fortuitous allies. Also described are private conversations between commanders, dreams in which the Prophet comes to give succour and hope to the weary, over 40 epistles between the young commander and his governor, conversations and agreements with local rajas of Hindustan, appointments of non-Muslims to administrative and ceremonial positions, discourses with astrologers and mendicants - all interspersed in the methodical military march of Muhammad bin Qasim through the kingdom of Dahir.

Most importantly, from the taking of Daibul to Multan, Muhammad bin Qasim's campaign is a deliberate mirroring of the campaigns that Chach undertakes to the 'four quarters' of his kingdom - al-Qasim even plants a Muslim standard at the very spot where decades before, 'Ali Kufi has Chach marking with a tree the extent of his kingdom. 'Ali Kufi's Muslim kingdom of faith, hence, explicitly restrains itself under the previous political boundary. The text concludes with the set-piece- the description of the end of Muhammad bin Qasim which comes after the Caliph in 'Baghdad' (an anachronism) is tricked by the daughters of Dahir to order the death of this young conqueror. Abruptly, Chachnama concludes, followed with just a short dedication and a prayer from 'Ali Kufi.

Following this brief synopsis of Chachnama, I note again that the text precisely labels itself a hikayat (stories, often told and heard orally), a ta'rikh (history), a dastan (epic) - and participates in those narrative voices accordingly. In its format, the narration of particular 'historical' episodes is sprinkled with discursive details of good governance and guidelines for conduct. It is this quality of the text, which makes Chachnama impossible to place in any singular genre. As a hikayat, there is far too great an emphasis on political, event-centred details. As a ta'rikh, there are too many digressions into good governance, into advice, into details of mysterious and mythical happenings, and most importantly, an unprecedented (for Arabic historiography) 'local pre-history' of the land that was opened for Islam - this at the expense of Islam's own cosmological pasts, as the details of the times of the Prophets from Adam to Muhammad are completely absent, replaced by the account of Chach.

The strongest visible stylistic influences apparent for Chachnama may be the Persian translation of Ibn Muqaffa's Arabic Kalila wa Dimna by Abu al-Fadl Bal'ami (d. 940) and Firdawsi's Shahnama which was written at the court of 
Mahmud at Ghazna in 1010 (another frontier history). Kalila wa Dimna was a collection of animal fables which originated in the Sanskrit Pancatantra and were translated into Pahlavi in the mid-sixth century. The Persian secretary for the late 'Umayyad regime, 'Abdallah bin al-Muqaffa' (d. 756), translated them into Arabic for the express purpose of creating a body of advice literature for the rulers (a 'Mirror for Princes'). ${ }^{12}$ Firdawsi's Shahnama tells of the rise and fall of three successive Iranian dynasties - each attempting to establish order but each falling into moral decay and disorder. What is notable in both of these texts is that the preIslamic past is not renounced or ignored or situated within an Islamic present- - but stands in direct conversation with it. Furthermore, the attempt at both critique and at guidance is not hinged on the Qur'an or Hadith. In contrast, for al-Baladhuri, and al-Tabari, the progression of time is linear and the teleology is directly focused towards the Prophet and then away from the Prophet, with the moral universe expanding and contracting according to the chronological distance from him. For Firdawsi, time is illuminating the cyclical pattern of rise and fall based on the moral qualities of the rulers, themselves. Chachnama uniquely blends these two strands of historiography - taking the cyclical universe of Firdawsi and planting within it the righteously guided history of al-Tabari. Unlike his contemporaries, such as 'Awfi or Juzjani, "Ali Kufi situates his history in Uch. He places his narrative immediately before the coming of Islam, followed by the conquest itself. He splices within this tropes from ethico-political literature, most prominently Ibn al-Muqaffa"s Adab al-Kabir. Again, unlike his contemporaries, he pauses the past by stopping the narrative with the death of Muhammad bin Qasim — abruptly breaking the tradition of contemporary history.

\section{'Translating' A New History}

In Chachnama's opening, 'Ali Kufi remarks that a book on the conquest of Hindustan and al-Sind to match those 'prose and verse books' on 'Khurasan, Iraq, Fars, Rome, and Syria' is missing, and that the arrival of Islam on the shores of this sea and 'the building of mosques and minarets from Kashmir to Qanauj' is thus left unheralded. ${ }^{13}$ Determined to correct this, he travels to Bhakkar where he finds such a history unknown to the ahl-e 'Ajam (non Arabs, broadly) in the possession of a learned and pious descendant of the very tribe of Muhammad bin Qasim. In a section titled, Tarjam-e Kitab (Translation of the Book), he writes:

When this slave became acquainted with the book, he found it to be full of jewels of wisdom and pearls of advice in which many examples of the bravery and

\footnotetext{
${ }^{12}$ There are greater parallels to 'Ali Kufi's program with Ibn al-Muqaffa' - two authors at a particularly tumultuous time envisioning a radically different future. See Arjomand, "Abd Allah Ibn al-Muqaffa and the "Abbasid Revolution", pp. 9-36.

${ }^{13}$ Fathnama-i Sind, p. 6.
} 
courage of Arabs and Syrians were inscribed, and their stature and intelligence was evident. Every fortification that they conquered, they ended the night of unbelief and ignorance. In every region they entered, they glorified Islam and erected mosques with minarets, and filled them with pious and ascetic believers. And to this day, the light of Islam, honesty, hard-work, and knowledge continues to shine in those regions. And in each epoch that a slave owned by the Prophet ascends to the throne, once again, he strips the rust of ignorance away from the mirror of Islam. ${ }^{14}$

'Ali Kufi is marking two explicit goals: that of linking this local history to the history of Arabs and promoting the concept of a 'renewal' of central principles of Islam. He is, in effect, linking the history of Uch to the originary moment of Islam in Arabia. He goes on:

When this dini dāstān (a fable of faith) was taken from the veil of Taz' $\bar{\imath}$ and the cover of Hijāzi into the hüjrā $-i$ 'Ajam (the house of Persian), and put in the strictures of narrative and the fabric of honesty, and translated into the sillk-i $n \bar{a} \underline{s} r$ (clothes of prose), I dove into the thoughts to which great leader this new and strange fath nāma (letter of conquest) can be dedicated. ${ }^{15}$

It should be noted, yet again, that he does not provide the name of the original text, nor does he provide any indications on its provenance. In his dedication, 'Ali Kufi provides a further hint about his project of linking this fath nama to an Islamo-Arabian history:

This fath näma which is composed for religious reward and worldly benefits, and which will become a source of pride for the coming generations, and researchers and kings alike will praise it. And everyone will be impressed by the strength of belief in Arabs and their status as those with knowledge and manners. And this fath nama will be a memorial to the grandeur and nobility of the inhabitants of Arabia and Syria. This fath namma should be given to one whose grand family is of Arab descent and at the hands of whose forefathers, the lands of Khurāsān and 'Ajam were conquered. ${ }^{16}$

'Ali Kufi means the chief minister of Qabacha, 'Ain al-Mulk Fakhr al-Din alHusain bin Abi Bark al Ash'ari, who traced his lineage back to the Quraysh and the Prophet. Such an intense focus on the 'Syrianization' of the ruling elite within the 'Persianization' of the text needs to be seen in the wider context of the struggle between the Yemeni Isma'ili $d a$ ' $w a$ forces and the Sunni orthodoxy in Uch and

\footnotetext{
${ }^{14}$ Ibid., p. 7.

${ }^{15}$ Ibid., p.7.

${ }^{16}$ Ibid., p. 8.
}

The Indian Economic and Social History Review, 49, 4 (2012): 459-491 
Multan for the centuries preceding 'Ali Kufi-a history of which, he must have been acutely aware.

\section{'Ali Kufi returns to the claim of translation in his closing remarks}

Even though this book contained great wisdom, a wealth of advice, and methods for the running of the affairs of governance; even if this book had a great standing in the language of Arabs and in the diction of Arabia, and the notables of Arabia read it with great fervour and were proud of it, yet, it was behind the veil of Arabic and devoid of the decoration and beauty of the zabān-i Pahlawi (Persian) and, for this reason, did not circulate outside of Arabia. From the people of Fars, no one adorned this bride of a fath näma; or dressed her with garments of exquisite language, justice and wisdom.

No mighty rider took this horse into the grounds of clarity and the gardens of loquaciousness. But when the hard accidents of the world headed towards this weak one ("Ali Kufi), and the harshness of the times anchored their sail in his chest, and all manners of difficulties asserted themselves, and everywhere he turned, he saw dangers and treasons, then in that same condition, this man of incomplete intellect, chose to finish this book. Praise be to Allah, the God of All. ${ }^{17}$

Hence, in both the beginning and the end of his text, 'Ali Kufi stresses that he is translating an original Arabic text (perhaps in verse) into Persian. Such repeated declarations have, understandably, led modern historians to claim Chachnama as a translation of an earlier 'history'. Contemporary historians, such as N.B. Baloch and Derryl McLean, point out that some 23 isnad within Chachnama contain an attribution to the Baghdadi historian al-Mada'ini. Since al-Baladhuri, al-Tabari and al-Ya'qubi all attribute their material on al-Sind to al-Mada'ini, it certainly cements Chachnama with impressive source credentials.

This claim of translation, and subsequently a recoverable pre-text, however, remains a hard case to make. While Chachnama follows the structure of alBaladhuri, it does not duplicate any of the isnad we find in al-Baladhuri, nor does the Chachnama name any particular work by Abu'l Hasan al-Mada'ini, or even give the name of the text of which it presumes to be a translation. When we look closely at the isnad in the Chachnama, we see two categories emerge. First, are the roughly 30 broad, generic citations, without any particular names, which follow literary conventions such as 'the wise of al-Sind say' or 'some of the Brahmins of al-Aror report'. Second, are those designed largely to provide the illusion of authoritative transmission, by quoting al-Mada' ini: 'Far sighted wise-men and wellmeaning elders report from Abu'l Hasan', 'Abu'l Hasan heard it from Hazli', and, only once a direct transmission, 'Muhammad bin 'Ali and Abu'l Hasan Mada'ini reports'. In contrast, al-Baladhuri's citation remains explicit 'al-Mada'ini stated',

${ }^{17}$ Ibid., p. 191. 
'It was reported by 'Ali bin Muhammad bin 'Abdallah bin 'Abi Saif' or 'Swore Mansur bin Hatim'. In contrast, 'Ali Kufi's narrative strategy seems to rest on claiming to the authority of al-Mada'ini while simultaneously eliding any traceable sources of transmission. The rather straightforward observation that 'Ali Kufi relied on a series of texts to compose an original work in Uch, speaking to the contemporary world via a history and an advice manual while couching his own skills through the ruse of translation seems the most plausible. One final bit of evidence being that that the one event 'Ali Kufi ascribes directly to al-Mada'ini is also considered to be the most 'fantastic' event in the whole text: the episode of the death of Muhammad bin Qasim.

I suggest that we re-evaluate Chachnama as a text of the early-thirteenth century which seeks to comment widely on its political and social present, and offer a range of possibilities for the many futures of Uch. In my reading, Chachnama is a complex text that draws upon a number of genres from Arabic and Persian historiography. It is a ta'rikh but not a simple aggregation of $a k h b \bar{a} r$ (reports) without a narrative thread. It is a dāstān (epic) with romances-such as Chach and Suhnan Deo, Dahir and his sister Ma'ian, Dahir's wife Ladi and Muhammad bin Qasim, Changi and Jai'sinah, and finally Muhammad bin Qasim and the two daughters of Dahir. It is also an adāb with advice and insh $\bar{a}$ (letters) between the commander and his governor. And most crucially, it is a vision of Uch's future, with the author providing a clear ordering of the known universe so as to provide a template for good governance. Where Chachnama draws on existing historical texts (in verse or in prose), it is a transmutation of those texts.

A number of explanations of the claim of translation by 'Ali Kufi can be forwarded: It should be understood as a literary gesture at narrative legitimacy and continuity. As is often noted in the examinations of Miguel Cervantes' opening of Don Quixote, the libros de caballerias contain an 'elaborate genealogy of translation...given to these narratives a more authoritative grounding' ${ }^{18}$ Such a literary gesture towards 'authoritative grounding' is a familiar trope in Persian poetics-such as the author's encounter with Khidr when embarking on a new writing project (the case of Firdawsi or Nizami being direct examples). ${ }^{19}$ Here, the isnad fulfil the role of fitting Chachnama within the historiography of his contemporaries at Uch and to soften the reception of this radically new text, which offered to re-cast local history as universal. We can also understand that it was 'Ali Kufi's attempt at cementing his appeal to 'Arabize' the credentials of Qabacha's court to the locality of Uch (by focusing on Arab Sind) in counter juxtaposition to the Ghurid warlords arrayed against him, Iltutmish and Yildiz, with the knowledge that 'finding' an original local text would bolster such efforts. However we choose to parse it, this much remains clear: 'Ali Kufi never cites a name for the original text, which he 'brought

\footnotetext{
${ }^{18}$ Polchow, 'Manipulation of Narrative Discourse', p. 75.

${ }^{19}$ See Franke, Begegnung mit Khidr.
} 
out of the veil of Hijaz', nor does he provide the name of an author or any direct citation of any other history that he used. Additionally, there are no texts outside of Chachnama derived from, based on, or referring to the events in 'Ali Kufi's narrative, as he framed it. Based on both inter-textual and extra-textual evidence, we can conclude that the Chachnama is not a translation of a unitary, pre-existing Arabic history of the eighth century and thus, we cannot utilise Chachnama as a primary source for the eighth century.

\section{Parsing Chachnama}

In revisiting Chachnama as a historically situated text from the thirteenth century and as a production of a key moment of present history, the underlying desire is to attempt a LeGoffian history of the imagination, though the task will remain far beyond the scope of this article. In creating Chachnama, 'Ali Kufi sought to explicitly imagine a past for Uch which conjoined an Islamic cosmology with its predecessor Brahmanic one. This act of imagination - a deliberate attempt to create a brand new, local past for the Turkic warlord Qabacha-utilised the dominant genres of ta'rikh, dastan, hikayat and adab. As both Kumar's work highlights, using numismatic and material evidence, that the Ghurid courts were fully engaged in transculturation and the usage of varied symbols and claims to authority, yet there remained a singular, exceptional quality to the Chachnama which cannot be found elsewhere.

Chachnama uses narrative techniques from all these genres to illustrate the cosmology within which it wants to situate the twin stories of Chach bin Sala'ij and Muhammad bin Qasim. 'Ali Kufi's text exists in a well-known scale of textsinteracting with standard histories of Muslim pasts, of newer forms of cultural imaginations, as well as, the non-Muslim world that surrounded it in the thirteenth century. In this section, I tease out some of these threads from Chachnama to show how seamlessly 'Ali Kufi interweaves genres and forms to construct this hybrid text — and argued for a hybrid form of political authentication.

\section{Ta'rikh in Chachnama}

To understand how seamlessly Chachnama incorporates these three narrative layers, we will look at one explicit portion of the text and see the process through which Chachnama takes the bare structure of a historical narrative and builds it up. Imagine if you will a reversal of the painful plucking of facts, so dear to modern historians. Given that al-Baladhuri's Futuh al-Buldan contains the largest amount of material attributed to al-Mada'ini and given that the arguments for the primacy (and translations) of Chachnama hinges on al-Mada'ini, I will compare the reporting of an event in al-Baladhuri to the Chachnama.

Al-Baladhuri begins his chapter with the conquest of al-Sind from the reign of 'Umar and the Arab attacks on the port cities of al-Daibul, Thana and Broach. 
Next he covers the time from 'Uthman to "Abd al-Malik and the campaigns that came via Makran. The third portion is the description of the frontier of al-Hind during al-Walid, and the renewal of a naval expedition to al-Daibul, followed by the campaign of Muhammad bin Qasim. The final section deals with the Arab governors and the re-conquest of various cities under the "Abbasids. Chachnama follows the template laid out by al-Baladhuri. It begins the narrative at the same point - with 'Umar - and re-states the key events according to al-Baladhuri. However, Chachnama greatly expands the narrative - adding military, political and social texture. Let us look at the earliest victory of Muhammad bin Qasim, the fall of the city of Daibul. First, is al-Baladhuri's account:

Then Muhammad bin al-Qasim left Arma'il, and with Juhm bin Zuhr alJu'fi arrived at al-Daibul on a Friday. There he received ships with men and weapons and supplies. After getting to al-Daibul, he constructed trenches around the troops and set up lances around the trenches and flags affixed to them. The armies were stationed under their flags. He installed a catapult known as 'Arus, which took 500 men to pull. In al-Daibul was a great budd (temple) with a tall flagstaff, and on that flagstaff was a red flag, which covered the city when it blew with winds. And they report that the temple had a great minaret built in the midst of the city, which housed their sanām (image). The temple was known by the name of the idols. Sometimes the idol is in the minaret - along with other things they worship. Everything they held in esteem, they consider it to be budd. And that is also a budd. And the image is also a budd.

Every third day, al-Hajjāj's letters reached Muhammad and Muhammad's letters with news of what he saw in front of him and his thoughts, reached al-Hajjāj. In a letter al-Hajjāj ordered Muhammad, 'Install the catapult 'Arus. Shorten the east-facing support. Call the operators of 'Arus and ask them to aim for the flagstaff-like the Romans - which you described to me'. The flagstaff was aimed at and broken and great distress spread through the unbelievers. Then Muhammad, attacked them after they attacked him and drove them back. He ordered ladders and men climbed them - the first being a man from the Murād of the people of Kufa. The city was conquered by force. For three days, Muhammad killed those within. The governor of Dāhir fled and the sādni (custodian) of their house of gods was killed. Muhammad declared it quarters for Muslims and built a mosque and settled 4,000 men. ${ }^{20}$

Al-Baladhuri's description has a narrative structure with some key hinges: the arrival of the army and the entrenchment, the catapult, the temple, the notice of communications, the first man to reach the top of the fort, the fall of the fort and finally the treatment of prisoners of war and sacred sites. Chachnama retains these narrative hinges, and builds an edifice on top of this structure that combines all

\footnotetext{
${ }^{20}$ al-Balādhurī, Futūḥ al-Buldān, p. 422.
} 
three of the narrative layers we discussed above: the history, the advice, and the story-telling. And in doing so, Chachnama broadens this episode into a panorama through which the interactions between believers and non-believers, the appointment of advisors and counsellors, and the moral universe of stars and gods are illuminated for the listener/reader. It takes the Arabic account and simultaneously makes it more Muslim and more Hindustani-by combining the two sources of sacred power, Allah and the local gods. And this is how Chachnama illuminates a new space for the inhabitants of Hindustan in Islamic cosmology.

First the arrival of the army and the setting up of the battle.

Preparation of the Arab army and the arrival of Hajjaj's letter

He left 'Arambil, and appointed Muṣ'ab bin 'Abd al-Rahmān to the advance brigade, Jāhm bin Zuhr al-Jāfì to the rear, 'Ațiyāh bin Sa'ad al-'Awfì to the left and Mūsā bin Sinān to the right. The rest of the sharp swordsmen and special forces, he kept in the centre with him and advanced. Then, on the day of the last Friday of the 93rd year of the Hijra, in the month of Muharram, he arrived at Daibul. At the same day, the naval forces, under Khurīm bin 'Umaru and Ibn Mughīra arrived. They gave him the letters from Hajjāj and advised him to dig a trench for the battle. And in the letters was written: 'I am sending special men to serve under you'.

Far-sighted wise-men and well-meaning elders told Abu'l Hasan who reported that he heard from a freed slave of Banu Tamīm Abu Muhammad that: Muhammad bin Qasim arrived near the fort of Daibul and his army dug trenches, planted their banners and beat their drums. Every brigade remained at the place where they were appointed and all the catapults were aligned. One catapult belonged specifically to the Amīr ul-Mu'minin (Caliph) and its name was 'Arusak - to operate which, five hundred men had to pull it to throw a stone.

In the centre of Daibul was a tall and grand but-kuda (house of an idol). And at its head was a dome, on which a green, silk banner waved. The but-khana was 40 yards tall and its dome was also 40 yards tall. The banner had four tongues - which when unfurled, each tongue pointed to its own direction and their rotations made them seem like towers.

When the people of the fort saw the army of Islam, they unfurled the banner and prepared for war but we did not have permission to engage them. In this manner, seven days passed.

Next, where al-Baladhuri gave the initiative to end the siege to Hajjaj, Chachnama introduces local actors:

Suddenly, a Brahmin emerged from the fort and asked for protection and said: 'May the Just Amir remain protected. Our books of astrology have this prediction: The vilayāt (polity) of Sind will fall to the hands of the army of Islam and the unbelievers will be routed. However, the banner of this temple 
casts a protective spell. As long as this banner flies, this fort will not fall. If you try and break the dome of the temple, the banner will be destroyed and the fort will be yours'.

After taking over Daibul, Muhammad bin Qasim orders the slaughter of all who resisted, as reported in al-Baladhuri but then comes the first account of governance, when he deals with the warden on the Muslim prisoners:

\section{Arrival of Qilā, the Warden}

The prisoners of Daibul were under the supervision of a man name Qila the son of Mahrtāj who was man of great intellect and abilities. He was an author and an expert writer and of good intentions. The troops of Badīl and the prisoners of Sarandip were under his supervision. Muhammad bin Qasim called him and ordered him punished. At which he said: 'Oh Amir of the armies of Islam, ask them what efforts I spend in their ease. When the truth is evident to you, then take away the order for my killing'.

Muhammad bin Qasim inquires from the Translator

Then Muhammad bin Qasim asked the translator: 'Ask him, what he did for the prisoners?' He said: 'Why don't you inquire with the prisoners themselves, so that the Amir knows my true nature'.

Inquiry from the Prisoners'

Muhammad bin Qasim called the prisoners in and asked them: 'What aid or help did this warden give you?' They all answered in one voice: 'We are thankful to him. He gave us all of his sympathy. He always believed that the Army of Islam will come for us and gave us hope in the conquest of Daibul'. Muhammad bin Qasim then invited him to Islam and he became a witness to God's one-ness. He appointed him to the rank of Nawab in Daibul. He was asked to mind the accounts of income and taxation on the country. And Hamīd bin Widāh al-Najdī was appointed Governor of Daibul and given control over the rights of the fort.

After settling the account of Daibul, Muhammad bin Qasim receives a letter from Dahir and Chachnama presents the first full picture of the competing world-view at stake. Note here the tension between the oppressed and justice:

Letter from Raja Dāhir

Bismīllah al- 'Azīm zi'l-wahadīnat wa Rabb-i Sil'āij (In the Name of the Great One Allah and the God of Sil'āij) This letter is from Dāhir bin Chach, the ruler of Sindh, the King of Hind and the Master of Land and Sea to the Headstrong and Deluded Muhammad bin Qasim who is so fond of killing and war and is so devoid of mercy that he doesn't even protect his own troops and propels them 
to their doom. Once before, there was a man with such a prideful dream. And he came here bearing an arrow of politics and Abū al-'Ạs al-Hakam was with him. On his mind was the obsession that he will conquer Hind and Sindh. One or two of my lowly lieutenants (thakūr) went to Daibul for hunting, and ended up killing him and defeating his army.

Now that same obsession is on Muhammad bin Qasim's mind and it will lead him, and his army, to the same suicidal path. If he did conquer Daibul, it was not a strong fort and there was no army stationed there. He conquered a town where artisans and traders lived. If there had been any notable there, no one would have found your remains. If I had given Raja Jaisini'āh bin Dāhir-who is the bringer of terror to the kings of this earth; the one who seeks vengeance from the oppressors of the time; an equal to Ascetics and to the Raja of Kashmir in his knowledge; holder of crown; at whose doorstep all the Raja of Hindustan lay their heads; all in Hind and in Sind are his servants and the polities of Tur'ān and Makrān wear his commands as their necklaces; who controls a hundred drunken elephants, and rides one white elephant; whom no horse can resist and none can stand in his way-permission, he would have taught you such a lesson that until the End of Days no army would have dared enter this realm. So, don't let pride ruin your head or your fate will be the same as that of Badīl. You don't have the capacity to battle with me, and neither do you have the strength to resist.

When this letter of Dāhir reached Muhammad bin Qasim, he had it translated by his secretary and after listening to it, wrote a reply with his own pen.

\section{Letter of Muhammad bin Qasim to Dāhir}

Bismillāh al-Rạ̣mān ir-Raḥim This letter is from Muhammad bin Qasim al-Thaqaî̀ who takes vengeance on behalf of Muslims from prideful rebels to the unbeliever, ignorant, apostate, proud Dāhir bin Chach Brahmin who rebels on the basis of this cruel time. Let it be known, that what you wrote was filled with the most ignorance and foolishness and that your opinions were corrupted and rank. I have read about your strength, bravery, weaponry, elephants, horses and armies and I have understood what you wrote. Our only strength and solace is in the One True God who arranges everything. Oh helpless one! Why do you take such pride in your elephants, horses and armies? An elephant is the basest being, devoid of all intelligence and power that cannot even defend its body from the tiniest mosquito. Those horses and riders that shocked you, were God's army.

It is only due to your ill-actions and your bad habits and your pride that we decided to attack your land. Because you stopped the ships from Sarandip and imprisoned the Muslims. Even though, the entire world heeds the commands of the Capital (where the Prophet's servants rule), you are the only one who rebelled. And that tax which had been due to the treasury - which your predecessors Kings and Governors understood as their duty-you stopped it. And 
when you embarked on these ill habits and did not stop and refused to yield to the Capital, then I was sent to take revenge on you for your doings. Wherever you will fight me, God - who helps the meek overcome the oppressors-will help me overcome you. I will conquer you, and dispatch your head to Iraq or I will sacrifice my life in the path of God. And this struggle is a jihäd against non-believers and apostates and it is necessary on me. I am grateful to God for giving me victory and I am hopeful that he will continue to find me victorious. God Willing, written in $93 .{ }^{21}$

Clearly Chachnama ensures that the overall narrative structure of this episode remains intact-as it appeared in al-Baladhuri. Furthermore, it includes those hinges - it mentions the name of the first person to climb the fort wall - which ground the narrative in ta'rikh. Similarly, it keeps the isnad - both generic and specific. But, it then surrounds the event in the second and third layers of adāb and hikayät. The story of the catapult, the warden and the exchanged letters are all micro-events that structure Chachnama's moral universe. It is in the final two letters - between Dāhir and Muhammad - that the Chachnama shows clearly what is at stake by invoking the source of true power in the universe - the One God. But, even as it stresses moral groundings in Islam, it does not exclude the non-believers from it. In the episode above, while there is one key member (the warden) who converts to Islam, his morality exists prior to his encounter with Islam. Similarly, the various priests are not demonised. It is instructive, then, that Chachnama does not use religious ideology as the sole basis for political power. Even as Muhammad bin Qasim describes his faith, he is careful to lay out distinct causus belli for the invasion: Dahir's inability to protect Muslim civilians, his refusal to honour past agreements and his refusal to pay taxes.

For the historian of the eighth century, the question that emerges from the above is: What did Chachnama add to our knowledge of the conquest, given that nothing in this account can be substantiated from other sources? The names of participants mentioned in the letters and in the descriptions are untraceable in the usual biographical dictionaries. The letters themselves do not fit the template for even the ninth century-following the insha traditions of the thirteenth century instead. Essentially, we cannot take, at face value, any of the additional details provided by the Chachnama as relating to the actual events as they might have transpired in 712. However, we can certainly use this event, and the letters, to observe how Qabacha and his ruling elite sought to situate themselves in relation to other imperial formations and their subjects.

This should not give the impression that Chachnama merely exaggerates alBaladhuri's narrative. That is, after all, the methodological assumption that has allowed historians to 'strip bare' the historical facts within Chachnama. In fact,

${ }^{21}$ Fathnama-i Sind, p. 74-81.

The Indian Economic and Social History Review, 49, 4 (2012): 459-491 
Chachnama's treatment of history is far more complex. I want to give two more examples where Chachnama situates history within a local context.

\section{The House of Gold}

Al-Baladhuri narrates that after the conquest of Multān, there was so much loot that the Muslim army dug a room into which they threw the gold - thereby giving al-Sind the name, 'frontier with the house of gold'. Chachnama situates this within a different, pre-Islamic context:

When Multan was conquered, the nobles of the city gathered and gave 60,000 dirhām weight of silver. Every member of the cavalry received 400 dirhām weight of silver. Then Muhammad bin Qasim said, 'We should think of the Treasury in the Capital'.

While they were discussing this, suddenly a Brahmin emerged and said: 'When the time of unbelievers is over, the temple is destroyed, and the world is illuminated with Islam's light, and in the space of temples, mosques have been erected, I heard from the elders of Multan: In ancient time and under past rulers, in this city was a king Jubān who ruled over Kashmir. He was a Brahmin man and a monk and strict follower of his creed. He spent his time worshipping his images. When his treasure exceeded the boundaries of counting and calculating, then in the east of Multan, he built a fountain, 100 yards by 100 yards. And in the centre of this fountain, he erected a temple of fifty yards by fifty yards. And in this temple, he built a cellar in which were 40 drums of copper. And in each drum were 330 tons (mun) of gold. And on top of this cellar, he had installed a red image. And around the four corners of the fountain, he installed trees'. ${ }^{22}$

Here, the fascination with gold, apparent even in the ninth and tenth century geographical accounts morphs a one-line description from al-Baladhuri into a remarkable description of near-heavenly treasure pre-dating Islam's arrival. With the establishment of this house of gold taken from the Muslim army and given to the Raja of Kashmir through the explicit task of imagining not just a basement of gold but a paradise-like structure that connects the Indo-Persianate imagination of heaven janat with the sacred geography of Hindustan. With the divinely ordained transfer of power to the Muslims, we get the very literal handing over, of Paradise. Chachnama, then, uses the akhbar reportage from al-Baladhuri and transforms it into yet another piece of evidence supporting the divine sanction of Muslims in Hindustan. Clearly, such concerns were illegible to al-Baladhuri in the ninth century but in the historical context of contested rule over Multan between Yildiz and Qabacha, they were central to 'Ali Kufi. This episode in Chachnama becomes

${ }^{22}$ Ibid., p. 183.

The Indian Economic and Social History Review, 49, 4 (2012): 459-491 
unintelligible as a history of the eighth century, but becomes profoundly descriptive as a history of the thirteenth century: a legitimising force.

\section{The Case of the Jats}

In another sense, the history in Chachnama also serves as legal and administrative precedent. The Muslim practices of taxation on civilians, of grants to and from neighbouring kings, of taking hostages from forts to ensure their continued cooperation are all given a 'history' with the Chach cycle of the text. In one key area-the social practices concerning a group of people, it is even explicitly linked to the pre-history of Islam's arrival in al-Sind. After Chach conquers the city of Brahmanabad, he imposes a tax on the people, along with a special arrangement for the Jat tribe from Lohana who had opposed Chach. Al-Baladhuri's narration of the event takes a few sentences: 'As Muhammad bin Qasim was en-route from Brahmanabad to al-Aror, he encountered the people of Sāvandrī who begged for peace. He granted them protection on the condition that when Muslims pass through their region, they host them and guide them. Now those people are Muslim' ${ }^{23}$

In Chachnama this narration expands to encapsulate the role of minorities within minorities:

Then Chach stayed in the fort of Brahmanabad and, for the sake of commerce and the safety of the people, he instituted an income. Then he called forth and humiliated the Jāts of Lohana and punished their leader and imprisoned him. And imposed on them the conditions that they will never carry a sword, nor wear clothes of silk or spun cotton. Their upper covering may be sewn but their lower covering cannot be sewn and must be of black or red colour. They cannot put saddles on their horses. They must never cover their heads nor their feet. When they leave their houses, they must be accompanied by a dog. They will supply the governor's kitchen with cooking wood. They will be employed as guides and spies. And they will cultivate such qualities, so that when an enemy approaches this fort, they will be able to defend it on their own honour. ${ }^{24}$

This first indication of the special status of the Jats is reinforced during the reign of Dahir. In the defence that he submits to his elder brother for marrying their sister, Dahir proclaims:

Even though Ma'īn is our father's daughter, she is a daughter of the Jāts who are by nature rebellious and criminal, especially their women. The reality is that, they can never be trusted, depended upon, or taken on their own words. This proverb on the Jāts is widely known: 'Whoever grabbed the leg of a goat, got

${ }^{23}$ Al-Balādhurī, p. 420.

${ }^{24}$ Fathnama-i Sindh., p. 33. 
milk. Whoever grabbed the hand of a Jāt woman, mounted her'. Since, Mā'in is by nature a stranger, marrying her is not a $\sin .^{25}$

The issue of Jats is revisited when Muhammad bin Qasim conquers the same fort of Brahamanabad. Until this moment, he has had only one guiding principle for dealing with the locals which was spelled out for him by Hajjaj-laws of their land (qanūn-i vilayāt) and illuminate the ways in which cities such as Multan had been governed for nearly two centuries. It is this same notion that propels Muhammad bin Qasim's treatment of the Jats:

Then he called the minister Siāker and Mokā and asked them: 'What was the matter of Jāts with Chach and Dāhir? And how was it conducted?' Minister Siāker replied: 'During the rule of Chach, the Jāts of Lohana, that is those who lived in the area of Lakha and Samma, were prohibited from wearing soft clothes, from covering their heads, and of wearing rough, black, sheet on their torso. When they exited their homes, they were accompanied by dogs; by this, they could be identified from afar. None of their elders could ride a horse. Whenever a king needed a guide, they were called upon to show the way. They indicated the pathways and guided travellers from one tribe to another. And when a leader among them rode a horse, that horse had no saddle or rein. However, he could put a cloth on the back of the horse. If anyone was hurt or killed during travel, it was from them that an investigation was made. And if someone from them was proven to be a thief, his family - including his wife and children-were burned. Caravans travelled by day and night, with them as guides. They do not respect their elders. They are barbaric, prone to rebellion and thievery on the roads. They were even in Daybul, raiding along with others. They are also responsible for bringing cooking wood to the kitchens of the kings.

Said Muhammad bin Qasim: 'How revolting are these people! They are like the jungle dwellers in the lands of Fars (Iran) and Kuh-paia (base of a mountain) who have the same ways'.

Hence, Muhammad bin Qasim kept on them their existing laws. Just as during the times of Amir al-Mu'minin 'Umar bin al-Khattāab had insisted that the inhabitants of Syria host any traveller for a night and given food, and if sick, for three nights. ${ }^{26}$

In dealing with the Jats, Chachnama again layers three levels of history for the audience of the thirteenth century: the existing rules of Chach, the precedent of Muhammad bin Qasim and then, as a legitimising force, the practice of the Rightly Guided Caliph. It is in these ways that Chachnama emerges as a hybrid text that represents only the past within which it was composed-the early-thirteenth

${ }^{25}$ Ibid., p. 44.

${ }^{26}$ Ibid., p. 163-64.

The Indian Economic and Social History Review, 49, 4 (2012): 459-491 
century. Its concerns are the concerns of a locale beset with political and military turmoil. Its intention is to ground the reality into an imagined past - that can provide a sustained, moral universe allowing its rulers and their advisors guidance in their present. The movement of the conquest episode from a simple akhbar in al-Balādhurī to a complex and layered take on the similarities and differences that under-gird the moral universe of conquest is a deliberate movement, and it shows the central concern of Chachnama as a text. It wishes to present a history-akin not only to al-Baladhuri but also to Firdawsi- that shows the necessary ingredients for a just and moral polity.

\section{Adāb in Chachnama}

Next I will highlight the second narrative structure, the $a d a b$ - through letters and direct speech-sprinkled throughout the Chachnama. In its structure, this genre, Fürstenspiegel, overlaps with works on ethics, governance and history. Though Chachnama does not correspond exactly to the structure of advice literature, there are 'conversations' between the counsellor and the king, as well as risala (epistles) with advice present throughout the text. In that, it inhabits the overall spirit of the genre- highlighting moral, ethical and just solutions to political problems facing the ruler.

Chachnama consists of two concentric cycles: the rise and fall of the Chach dynasty and the arrival and departure of Muhammad bin Qasim to Sindh. Within these mirrored narratives, Chachnama proposes a theory of just and legitimate rule, sources of morality, pre-destination and good conduct. Both Chach and Muhammad rise because they are devout, just rulers who pay attention to the needs of the common citizenry. The aristocratic-ministerial model of governance applies in both cycles - the advice of counsellors remains the necessary condition for governance. When Chach ascends to the throne, it is because he comes from a family of 'ascetics who dedicated their lives to the fire-temples' and has the legitimacy to be the king due to the fact that 'it is written in the books of Hind that when a soul spends its time in prayer and ascetic conduct, upon death it is reborn into the body of a King'. ${ }^{27}$

However, the earliest elucidation of Chachnama's political theology appears when Chach's minister Budhiman explains to Chach the state of the polity that he now controls:

The vizier (minister) bowed to the ground and said: May Raja Chach live long. Know that this throne and this capital and this sultanate have always remained under one King - and his governors have been faithful and loyal servants. When this mamlaka (realm) came to Raja Sīhäras Rai and he was defeated by the armies of Fars, then this became the kingship of Rai Sahāsi. He appointed four

${ }^{27}$ Ibid., p. 21.

The Indian Economic and Social History Review, 49, 4 (2012): 459-491 
different governors to each region so that they would dedicate themselves to gathering the taxes and protecting the boundaries. The Raja remained worried about his arrangement and wished to free his mind of such concerns. For this, he ensured that his army was strong and ready. If a weakness is not eliminated fully, the passage of time can turn it into a terrifying accident which can no longer be stopped. And when the land is protected and in strong hands, the heart is at ease. And then the neighbouring rulers and enemies will also pay attention and come give their respect.

I am hopeful that when you have a strong and brave army with drunk elephants, then you, too, will have peace of mind and the Supreme God will open new venues of conquest and victory for you and subjugate your enemies. I have hope that God will strengthen your rule and the four governors will wear the band of your slavery around their necks and all of your worries will be for naught and the opposing swordsmen will tremble and wear the garland of obedience around their necks. And this great land will prosper under your guidance and by your breath expand. For this to occur, a king must be brave and courageous and obey the command of God, alone. The same God who put you on the throne will also give you the strength to pursue your dreams and your hopes. ${ }^{28}$

The successful ruler, therefore, creates a strong army, installs trusted governors and then deals with his opponents from a position of strength. Hajjaj who takes on the role of the advisor during Muhammad bin Qasim's cycle of Chachnama provides this same advice:

In the Name of God, the Most Merciful and Benevolent. Dear son, what is the matter with you? Why are you so reluctant to use your intellect and your reason in your service? I only hope that you overcome all the kings of the East and destroy the cities of the unbelievers. Why are you reluctant to succeed in this endeavour? And overcome the evil of the enemies? I am hopeful that all of their plans will come to naught. They are planning to defeat the army of Islam, you keep your heart strong and whatever you need to spend, spend it. Shower his (Dāhir's) enemies with gifts and grants.

Whoever asks for a land grant or a governorship, do not make them hopeful. Instead, agree to them and sooth them with your commands and your agreements. Because there are four ways of becoming a king: first, peace, compassion, civility and companionship. Second, by spending wealth and granting gifts. Third, by understanding the proper reasons for their enmity and investigating their nature. Fourth, by fear, terror, courage and strength.

Dispatch your enemies by any means. When governors appear in front of you, agree with their just demands. When they announce taxes on themselves,

${ }^{28}$ Ibid., p. $22-23$.

The Indian Economic and Social History Review, 49, 4 (2012): 459-491 
accept them with grace and accept all that they send to the Treasury. Keep everyone calm. ${ }^{29}$

One crucial lesson in Chachnama is to negotiate only from a position of strength-Muhammad bin Qasim is repeatedly advised to grant mercy only after he has killed all military personnel or destroyed the inhabitations of the army. He is told, by Hajjaj, to offer sanctuary on his own terms alone. Read within the historical realities of Qabacha, these constructions of political advice could not be clearer in setting up a strict hierarchy of power relationships and the position of the monarch at the centre.

To highlight the use of anecdotes let us look at one such instance in Chachnama. This occurs during the final phases of the Chach dynasty — when Dahir is preparing to commit the moral crime of marrying his own sister, in order to keep the throne. $\mathrm{He}$ is concerned that such an act would repulse his nobles and they will revolt against him. His minister 'Budhiman' decides to conduct an experiment:

When minister Budhimān returned home, he called for a sheep and covered its back in earth and mustard seeds and watered it day and night, until the flowers bloomed. Then he let the sheep out of the house and everyone, big and small, town-dwellers and villagers, looked at it in great wonder. Until three days had passed and the sheep continued to wander the town, and all forgot it. The minister said, 'O King! Whatever the rumour is, it only stays on tongues for three days. After that, no one remembers its good or evil. Since you do not want to give up the throne and your heart is set on this matter. These people will not revolt against you. Hence, you should simply do it. ${ }^{30}$

With this advice, Dahir marries his sister and the cycle of Chach's dynasty begins its decline. Chachnama does not comment directly on the immorality of his action, but in the letter of Muhammad bin Qasim to Dahir, it is made clear that the fall of the Chach dynasty was brought about, in part, due to this immoral act. As we turn to the last narrative layer in Chachnama we will discuss - the hikayāt (story) - it is worth noting that the story of Dahir's marriage to his sister is one of the set-pieces used to illustrate the power - constitutive and destructive — of the feminine agents.

\section{Hikayat in Chachnama}

This third narrative layer of Chachnama, though scant, is perhaps the most conspicuous in the text. While Chachnama begins a number of reports with some form of attestation that it is a hikayat - in a general pattern of aggregating or generalising the sources - there are only a limited number of 'tales' or 'stories' that stand out

${ }^{29}$ Ibid., p. 94-95.

${ }^{30}$ Ibid., p. 41.

The Indian Economic and Social History Review, 49, 4 (2012): 459-491 
in the narrative. Partly, because Chachnama succeeds brilliantly in meshing such elements within the other narrative layers but also because Chachnama does not explicitly want to draw attention to its story-telling. Still, hikayat as a function of story-telling emerges in two themes: episodes of romantic love and seduction, and the supernatural. I will only provide an example of the latter.

The voice of the supernatural in Chachnama is usually the voice of prognostication: the astrologers and soothsayers. In one episode a magician (sāhirāa) uses her abilities to confirm for the people of al-Aror that Dahir had indeed been killed by the invading army. In another, Hajjaj has a dream about the death of a commander before the news reached him and he prophesies to the people of Kufa that it will be Muhammad bin Qasim, who will conquer Hindustan. These episodes give us a tantalising glimpse into the social functions of the supernatural in early-thirteenth century Sindh-from the prophetic power of dreams to the cross-denominational belief in pre-destination.

The supernatural also frames the divine hierarchy of Chachnama and give the listener/reader a sense of how the godly world is structured - through the stories of Chach and Muhammad bin Qasim - linking history, advice and story-telling. These two episodes also serve as an introduction to the main set-piece of the Chachnama and its most explicit (and greatest) story: the death of Muhammad bin Qasim. They establish the clear hierarchy that Chachnama constructs between the theists in Uch. Chach himself is from a priestly family, and is often referred to as a 'Brahmin'. Next are the samani, which are understood to be Buddhists in Persian sources. The third category of course, are the Muslims. ${ }^{31}$

The first hikayat to highlight is the encounter between the Brahmin Chach and a 'nasīk samāni' (Buddhist caretaker/monk) who resisted the attempts of Chach to conquer Brahmanabad. He was known as budh rakuh (one who protects the Buddha) and had elaborate spells that kept Chach from claiming the fort for over a year. This enraged Chach who vowed to 'skin him and send his skin to the royal drummers so that they can stretch it across their drums and beat on it every day'. ${ }^{32}$ After the fort fell, Chach gathered his armed troops and rode towards the temple. On the way, he told them that he would go into the temple alone. Upon his return, they were to watch for his signal, and once given, fall upon the monk and kill him. With all this arranged, Chach enters the temple grounds and finds the monk sitting, constructing and stamping miniature clay idols. After letting him stand for an hour, the monk finally looks at Chach and says: 'Ah. The son of Sil'aij the monk is here. What do you want?' Chach sits down and explains that he would like to have the monk involved in daily administration of the city and help with the task of rebuilding it after this war. The monk refuses Chach's offer, saying that his concerns are only

\footnotetext{
${ }^{31}$ Incidentally, only in one instance are the Muslims shown being externally referred to: Dāhir's wife Ladi calls the invading Muslims, an army of 'chandalān gao-khawār' (lowest caste cow-eaters). This 'insult' is repeated once again but draws no rebuke from Muhammad bin Qasim. Ibid., p. 147.

${ }^{32}$ Ibid., p. 30.
} 
with God and not with the king. They debate this for a while and finally, Chach asks if he could, at least, give a grant to the monk. The monk refuses even this. Chach then asks if he could give a grant to the temple. The monk replies: 'Only if your intention is good and for charity. This temple of Budh called kanohär is ancient and it is in ruins from the passage of time. Rebuild it and spend your money on this task and you will, in this manner, help me'. Chach agrees. Then:

Chach climbs his horse and returns. The minister says: 'O King! I saw a strange thing'. He asks, 'What?' The Minister replies: 'The king was determined to kill that monk and had ordered sword-bearers to draw their swords. But when you reached him, you fell to asking his pleasure. And accepted his request'. Chach says: 'Yes. I saw a strange vision which had no magic or trickery in it. And when I saw it, I saw in it clear signs. When I sat in front of the monk, I saw a vision - terrifying and horrific — which stood behind him. Its eyes were red like fire, its lips were thick and hung, its teeth were sharp like knives. In its hand it carried a mace of silver, raised as if to strike. I was frightened of that vision and did not dare speak as I had spoken earlier. I was afraid for my life, and left as soon as I could, giving the grants that I could'. ${ }^{33}$

This presence of the supernatural in the natural world is highlighted next in the two encounters of Muhammad bin Qasim inside temples. Note, in the first instance, the similarity in the 'eyes' to the Chach story:

Muhammad bin Qasim entered the temple with his assistants and his commanders. They saw an image which was made of gold and had two eyes glowing red like rubies. Muhammad bin Qasim thought this to be a man. And he unsheathed his sword and stepped forward to strike it. The Brahmin caretaker of the but said: 'O Just Commander! This is an idol made by Jabūn'. ${ }^{34}$

On a narrative level, this clearly connects the cycles of Chach and Muhammad - where the first is cowed by the demonic presence (and older faith) the second moves to confront and subdue it. The next encounter allows Chachnama to demonstrate the superiority of Muhammad bin Qasim's theism more explicitly:

When Muhammad bin Qasim entered the fort, all of the city dwellers gathered at the temple of Nau Bahär and prostrated themselves and began to worship the idol. Muhammad bin Qasim inquired, 'Whose house is it where all men, great and common, are praying next to each other and prostrating themselves?' They replied, 'It is a temple (büt kuda) which they call Nau Bahār'. Then Muhammad bin Qasim ordered the temple doors opened and he entered it with his nobles. He

${ }^{33}$ Ibid., p. 32.

${ }^{34}$ Ibid., p. 184.

The Indian Economic and Social History Review, 49, 4 (2012): 459-491 
saw an image, made of marble, seated on a horse, on whose wrist were bracelets of gold and rubies. He called out to the caretakers, and asked, 'Is this your idol (sanām)?' They said, 'Yes. Except his wrist had two bracelets. We only see one, now'. Muhammad bin Qasim said, 'Can't the one you worship (mäbud) even know where his bracelet went?' The caretaker lowered his head. Muhammad bin Qasim laughed and returned the bracelet. ${ }^{35}$

In the cosmology of beliefs, in Chachnama, the Muslim domination is explicit, yet dialogical. It acknowledges other theists, granting them special knowledge, rules and imaginations. These 'faith' encounters are explicitly separated from the militarily and politically determined encounters. The domination over the sacred spaces of the vanquished is imagined as a constitutive part of military supremacy.

\section{The Long Thirteenth Century of Chachnama}

I have already mentioned that an early reference to the Chachnama comes in Insha'-i Mahru. What is notable is that Chachnama is not cited in any of the major Persian works produced in Delhi between the mid-thirteenth and mid-fourteenth century. Partly, this is due to the fact that both political power and the scribal community shifted north from Uch. It is only when the centre of Delhi is gripped in political turmoil with al-Sind that chronicles cite Chachnama. It re-surfaces during the reign of Akbar (1542-1605) in Nizammuddin Ahmad's Tabaqat-i Akbari (completed in 1593) and in Mir Muhammad Ma 'sum Bhakkari's Ta'rikh-i Ma 'sumi (completed in 1600) - at both times tied to Akbar's campaigns to the north-west. Smaller excerpts and references to the Chachnama appear in Muhammad Qasim Firishta's Gulshan-i Ibrahimi (1606), the Beglarnama (1608), Mufzal Khan's Ta'rikh-i Mufazali (1712), and 'Ali Sher Qanai's Tuhfat al-Kiram (1768). In general, it is not mentioned in texts written further afield than Lahore from Uch.

After the arrival of the East India Company in Sindh, in the early decades of the nineteenth century, Chachnama entered the British colonial historiography. The earliest mention is by Captain James McMurdo (d. 1820) who travelled the Indus in 1812, and mentioned precisely that it was the text offered by local tradition as its authentic history. Both Lieutenant Thomas Postans (d. 1846), and his colleague Richard F. Burton (d. 1890), translated parts of the Chachnama in their respective travelogues. All of these translations treated Chachnama as an 'authentic' source of history of the region, a 'translation' of a no-longer extant Arabic original and, hence, the best source for an event that preceded the text by 500 years. This characterisation allowed the colonial officer to reflect back the political and cultural realities of the thirteenth century, captured in the Chachnama, to Islam's originary moments and, thence, towards an epistemic break in Indian pasts. An early

${ }^{35}$ Ibid., p. 172.

The Indian Economic and Social History Review, 49, 4 (2012): 459-491 
historiographical verdict on Chachnama was delivered by Mountstuart Elphinstone (1779-1859) in his 1841 History of India: The Hindu and Mohametan Periods (the text is bought to his attention by McMurdo): 'Though loaded with tedious speeches, and letters ascribed to the principal actors, it contains a minute and consistent account of the transactions during Mohammed Casim's invasion' ${ }^{36}$ Henry Miers Elliot (1808-1853) translated major portions of 'Ali Kuf's text which he deemed had 'an air of truth' about them but it had to be carefully excavated. It is via these excerpts that nationalist historians turned to the history of Islam's arrival and to the Chachnama.

In 1900, prominent Sindhi author and translator Mirza Qalich Beg noted the deficiencies in the Elliot's translations and published the first full English translation of the Chachnama. This was followed by a critical Persian edition published in 1939 by historian Umar bin Muhammad Daudpota. However, Daudpota's critical edition remained incomplete as he was unable to utilise the earliest extant manuscript of the Chachnama, copied in 1650. That admirable task was completed, in 1983, by the paramount historian of Sindh, Nabi Buksh Khan Baloch whose Fathnama-i Sind remains the latest Persian edition of the Chachnama.

The selections (and verdicts) of Chachnama rendered by Elphinstone and Elliot became the dominant framework for the nationalist historians who joined the ongoing conversation regarding Muhammad bin Qasim - the imperial usurper and temple desecrator. Two central assumptions were made about the text: first, that its primary value was as a source for the eighth century accounts of Muhammad bin Qasim because it was a translation of an earlier, no longer extant Arabic history and second, that anything that could not be mined for historical fact was romantic gibberish clotting the text. These assumptions led the nationalist historians to treat the Chachnama as a carrier-text (it carries within it an older, more reliable text) which had to be carefully stripped bare and re-assembled into a 'historically accurate' narrative. Such an approach removed any need to read the text as a whole, observe the inter-textual connections between the histories of Chach and Muhammad bin Qasim, examine the moral universe created or even place it within the specific landscape of Uch - it became a universalised conquest narrative of early Islam. Such oversights found little corrective, as this limited and misleading reading of Chachnama as primarily a history of the eighth century became standard.

Hence, nationalist historians like Mohammad Habib (1895-1971) dismissed in entirety the pre-Islamic section of the Chachnama and enthusiastically embraced the rest as an authentic source for the eighth century Muslim conquest: 'We may, therefore, confidently trust the Chach Nama as the safest of guides of the invasion'. ${ }^{37}$ Even those with more scepticism, were willing to parse out the historical truth from the romantic. R.C. Majumdar (1888-1980) declared Chachnama to contain 'a kernel

${ }^{36}$ Elphinstone, History of India: The Hindu and Mahometan Period, p. 303.
${ }^{37}$ Habib, 'Arab Conquest of Sind', p. 184.

The Indian Economic and Social History Review, 49, 4 (2012): 459-491 
of historical facts', though, it needed inherent fact-checking from archaeological and textual sources.$^{38}$ The portions of the Chachnama that did not speak directly to Muhammad bin Qasim's conquest became redundant and discardable, as Hodivala commented in his critique of Elliot's translation:

The whole of the first part of the work is overgrown with legendary matter and all but valueless as history. The description of Chach's conquests from Multān on the one side to Makrān on the other seems imaginary. It looks like rifaccimento in Persian prose of a poetical 'Digvijaya' and is every whit as unhistorical as similar lucubrations of Sanskrit poets and Rajput bards... It may have some basis in the flotsam and jetsam of local tradition, but if so, the tradition has been so grossly corrupted in the course of transmission by the fantastic accretions of subsequent inventiveness, as to amount to a travesty of the truth. ${ }^{39}$

The Chachnama had already inherited from the colonial historians a marked valence as a politically sensitive text unveiling the destruction of the golden age of India (pre-Muslim classical period) by the invading Muslims, and the subsequent ushering in of India's dark ages (the medieval period). In the backdrop of this historiographical debate - as the discussion over the destruction of Somanath exemplified-Chachnama had to be read as a history of the eighth century and not that of the thirteenth century, during which it was produced. This view of the hidden 'historical' value of Chachnama crystallises in the works of post-colonial scholars such as H.T. Lambrick, Peter Hardy and Yohanan Friedmann (Lambrick, 1973; Hardy,1981).

They chose to systematically and thoroughly separate the history from the 'flotsam and jetsam' that surrounded it. Names of people and places, dates of events and actions of political, religious or socio-cultural significance were teased out and, where available, carefully compared with Arabo-Persian biographical dictionaries, histories and chronicles. The notion of Chachnama as a carrier-text-it carries within it an older, more reliable text-became the overarching consensus of the field. The fact that the majority of Chachnama cannot be corroborated from any other source - textual or otherwise - is dealt with by relying on 'Ali Kufi's own testimony that his text is a translation from an earlier Arabic text, as Friedmann notes:

Though numerous other persons who appear in the Chach Nāma are not to be located easily in Arab historiography, one has the distinct impression that Küfí had the Arab tradition at his disposal and used it extensively. The Chach Nāma thus seems to be the only extant book which contains the detailed Arab tradition regarding the conquest of Sind. ${ }^{40}$

\footnotetext{
${ }^{38}$ Majumdar, 'The Arab Invasion of India', p. 13.

${ }^{39}$ Hodivala, Studies in Indo-Muslim History, p. 83.

${ }^{40}$ Friedmann, Origins and Significance, p. 28.
} 
From within this framework, the historian sifts through the romantic for the historical and builds a cohesive argument for a 'what happened' testimony of the Muslim past in India. The best of such scholarship such as Derryl N. Maclean's Religion and Society in Arab Sind (1989) go beyond Chachnama to add markedly important insights into the eighth century world but the ill effects of unmooring Chachnama from the Uch of early-thirteenth century remains. The lack of discussion of Chachnama in the exemplary scholarship of Sunil Kumar or Finbarr Flood towards making sense of the thirteenth century is one clear example of this ill effect. The historiographical consensus of placing Chachnama in the eighth century and mining it for facts made it invisible to the task of fleshing out the political and material history of the period undertaken by Kumar and Flood. Yet, the task of turning to Chachnama as a text of the thirteenth century carries with it a responsibility to situate Chachnama in the region-which means we need to look beyond the cityscape and towards the political and fantastical imaginative space; the frontier-space of al-Sind.

The other ill-effect has been in the usage of Chachnama in secondary scholarship on the post-colonial nation-states, issues of conversion or temple-desecration. I will not detail every single post-colonial work that utilised the historicity of Chachnama, but it would be useful to show how firmly the historical analysis of the earliest Muslim presence in India relies on this particular understanding of the Chachnama. A recent, popular, introductory history textbook, Modern South Asia, calls it 'the principal source of our information on the Muslim conquest of Sind' ${ }^{41}$ In reading Chachnama as a carrier-text, we enable 'Ali Kufi's reconstructions of a distant past as that past though, ultimately, we read it through our own particular presentist prejudices. Here, Chachnama becomes a political text of an entirely different sort. Take this verdict delivered by novelist V.S. Naipul on the Chachnama:

The Chachnama is in many ways like The Conquest of New Spain by Bernal Díaz del Costillo, the Spanish soldier who in his old age wrote of his campaigns in Mexico with Cortes in 1519 and after. The theme of both works is the same: the destruction, by an imperialist power with a strong sense of a mission and a wide knowledge of the world of a remote culture that knows only itself and doesn't begin to understand what it is fighting. ${ }^{42}$

It is this anachronistic reading of Chachnama as encapsulating some 'long lost' and 'true' history which allows Naipaul to bemoan the destruction of a 'purer' Indic past and to claim it for history. Naipaul takes this notion of 'lost history' from Chachnama itself, which is claimed by 'Ali Kufi to be a 'translation'. To 'Ali Kufi, it was not lost in the literal sense that it had remained hidden in a trunk covered in an incomprehensible language but that this history

${ }^{41}$ Bose and Jalal, Modern South Asia, p. 20.

${ }^{42}$ Naipaul, Among the Believers, p.13.

The Indian Economic and Social History Review, 49, 4 (2012): 459-491 
was lost in the metaphorical sense that the 'Turkic' Qabacha has no access to this originary moment of Islam in the very landscape where he was arguing for primacy. The political function of Chachnama in the nineteenth and twentieth century's is worth examining in its own right - and I hope to treat it fully in my monograph - but what we must do here, is separate our reading of 'Ali Kufi's text, produced in the thirteenth century, from the eighth century.

A text such as the Chachnama must be read within its own site of production as a particular act of agentive politics, with its own specific political and social goals. It should focus our attention on the regional framework-in this case, the internal frontier of Sindh. Chachnama is located specifically in the early thirteenth century world of Qabacha and Iltutmish. 'Ali Kufi proposes a radically new vision of the future by linking, stylistically, functionally and historically, the Indic and Islamic pasts in Uch. As such, he offers a political theology for Qabacha that both links him to the Sunni Arab heritage (Qabacha being of Mongol Turkic descent, and with access to the Arabic language) and to the much more powerful Indic empires to his East. In this politically volatile world, a way of creating alliances across the Rajasthani desert to Qanauj, meant composition of a radically new type of text - one which combines genres, affects and a new historical teleology.

It is precisely this regional configuration that also accounts for the persistence of Chachnama in the political history and memory of Uch today. For centuries, we find its echoes in popular memory, whenever political turmoil grips this region anew. From Akbar's invasion of Sindh, to the British invasion to the Partition of 1947-each moment of crisis, heralds a return to understand the tumultuous past of this region, and the text of Chachnama becomes the obvious, first step. It is, after all, a text situated in the landscape of Uch: it begins with its centre in al-Arōr and never leaves Sindh. This makes it the very first localisation of Islam's universal history in India and, as such, an important text for the purpose of understanding imagination of the thirteenth century Indo-Persian milieu. It is worth thinking about the conceptual geography that emerges from within Chachnama and what we can decipher of the thirteenth century through it. It argues for a sustained cultural engagement with Islam's others in the region. It posits four 'corners' of the region - all bordering non-Muslim kings. Within the text, it demonstrates how a just King (first Chach, and then Muhammad) would need to control everything up to the border of the region and from that point, exert dominion and influence on his neighbours. It shows the creation of agreements and partnerships between the varied faiths and it provides a framework within which Islam's universalism can exist as regionalism. What makes such a narrative possible is the position of Uch itself, in the early thirteenth century, as a frontier space filled with possibilities. Far from the capitals of Baghdad, Ghazna, and removed even from the new bases in Lahore and Multan, Uch harboured a conceptual geography where new possibilities could emerge. Obsessed as it 
is with boundaries, it is easy to read Chachnama as a frontier text, making an argument for its own centrality. Though Chachnama has never been considered a 'classical' text, it should be afforded renewed literary and historical attention for what it reveals about a moment of possibility in a remote frontier of empires.

The long political afterlife of Chachnama remains in play in today's Uch Sharif. In July 2012, some Sindhi nationalists started a Facebook group commemorating the '1300th Death Anniversary of Great Martyr of Sindh: Maharaja Dahir' and asked people to change their profile picture to an imagined depiction of Dahir. It bears repetition that the sole source for Dahir is the Chachnama - the Sindhi translation, done in 1930 - remains in print, along with an abridged version in English. The Sindhi nationalist claim to the legacy of Chachnama rests precisely on the historiographic judgement which places the text far before its thirteenth century milieu. Hence, the task of the historian - the ethics of reading - is to write on history and historiography simultaneously.

\section{References}

'Ain ud-Din. 'Ain ul Mulk Abdullah bin Mahrū, Inshā-i Māhrū, A. Rashid, ed., Lahore, 1965.

Ali, D. Courtly Culture and Political Life in Early Medieval India, Cambridge, 2004.

Arjomand, A. "Abd Allah Ibn al-Muqaffa' and the "Abbasid Revolution"', Iranian Studies (Special Issue: Religion and Society in Islamic Iran during the Pre-Modern Era), Vol. 27, 1994, pp. 9-36. al-Balādhurī. Futūḥ al-Buldān, 'A.A. and 'U.A. al-Tabbā', eds., Beirut, 1988.

Bose, S. and A. Jalal. Modern South Asia: History, Culture, Political Economy, New York, 2004.

Dagenais, J. The Ethics of Reading in Manuscript Culture: Glossing the Libro de buen amor, Princeton, 1994.

El-Hibri. T. Reinterpreting Islamic Historiography: Hārūn al-Rashīd and the Narrative of the 'Abbāsid Caliphate, Cambridge, 1999.

Elphinstone, M. History of India: The Hindu and Mahometan Period, London, 1911.

Fathnamah-i Sind, N. Baloch, ed., Islamabad, 1983.

Franke, P. Begegnung mit Khidr: Quellenstudien zum Imaginären im Traditionellen Islam (Encounters with Khidr: A Study on the Sources of the Imaginary in Traditional Islam), Stuttgart, 2000.

Friedmann, Y. 'The Origins and Significance of the Chach Nāma', in Yohanan Friedmann, ed., Islam in Asia, Vol. 1: South Asia, Boulder, 1984, pp. 23-37.

Habib, M. 'Arab Conquest of Sind', Islamic Culture, Vol. 3 (1929), pp. 184-93.

Hardy, P. 'Some Studies in Pre-Mughal Historiography', in C.H. Philips, ed., Historians of India, Pakistan and Ceylon, London, 1961, pp.115-27.

_ 'Is the Chach Nama Intelligible to the Historian as Political Theory?', in H. Khuhro, ed., Sind through the Centuries, Karachi, 1981, pp. 111-17.

Heck, P. 'Genres, Values and the Construction of Knowledge: The Islamic Sources', Al- 'Usur al-Wusta: The Bulletin of Middle East Medievalists, Vol. 13, 2001, pp. 34-36.

Hodivala, S.H. Studies in Indo-Muslim History: A Critical Commentary on Elliot and Dowson's History of India, Bombay, 1939.

Judd, S. 'Narratives and Character Development: al-Tabarī and al-Balādhūrī on Late Umayyad History', in Sebastian Günther, ed., Ideas, Images and Methods of Portrayal: Insights into Classical Arabic Literature and Islam, Leiden, 2005, pp. 209-25.

Kapstein, M. The Tibetan Assimilation of Buddhism: Conversion, Contestation, and Memory, New York, 2002.

The Indian Economic and Social History Review, 49, 4 (2012): 459-491 
Keshavmurthy, P. 'Finitude and the Authorship of Fiction: Muhammad 'Awfi's Preface to his Chronicle, Lubab al-Albab (The Piths of Intellects)', Arab Studies Journal, Vol. 19, 2011, pp. 118-22.

Kumar, S. The Emergence of the Delhi Sultanate, Delhi, 2007.

'Qutb and Modern Memory', in S. Kumar, ed., The Present in Delhi's Pasts, Delhi, 2010, pp. $1-37$.

Lambrick, H.T. Sind, Before the Muslim Conquest, Hyderabad, 1973.

Lamoreaux, J. The Early Muslim Tradition of Dream Interpretation, Albany, 2002.

MacLean, D. Religion and Society in Arab Sind, Leiden, 1989.

Majumdar, R.C., 'The Arab Invasion of India', Journal of Indian History, Vol. 10, 1931, supplement. Naipaul,V.S. Among the Believers: An Islamic Journey, New York, 1982.

Peterson, D. 'Review of The History of al-Tabarī, Vols. 8 \& 16', International Journal of Middle Eastern Studies, Vol. 31, 1999, pp. 124-26.

Polchow, S. 'Manipulation of Narrative Discourse: From Amadís De Gaula to "Don Quixote"', Hispania, Vol. 88, 2005, pp. 72-81.

Rao, V. N., D. Shulman and S. Subrahmanyam. Textures of Time: Writing History in South India 1600-1800, Delhi, 2001.

Sheikh, S. Forging a Region: Sultans, Traders, and Pilgrims in Gujarat, 1200-1500, Delhi, 2010.

Siddiqui, I.H. Indo-Persian Historiography up to the Thirteenth Century, Delhi, 2010. 